\title{
Seminatural silviculture in Southwest Germany ${ }^{1}$
}

\author{
by Peter Spathelf ${ }^{2}$
}

A brief historical overview shows the mainstream development pattern in German silviculture and outlines the adjacent role of naturally-oriented silviculture. The rationale for seminatural silviculture is discussed with reference to its ecological and economical aspects. Elements of seminatural silviculture of the BadenWürttemberg-concept are introduced. This concept is not purely a preservation strategy, but recognises the importance of timber production. Some aspects of selection forests, such as the special case of uneven-aged forests with a long tradition in Southwest Germany, are mentioned. As there are still a lot of even-aged (pure) forests in Southwest Germany, transformation strategies towards uneven-aged mixed forests are shown with the aid of some examples.

Criteria and indicators for seminatural silviculture which have to be developed on a regional or local scale, can be used as a basis for establishing a certification process for Southwest German forests. Seminatural silviculture is suited as a rational and integrating silvicultural system to fulfil future requirements on forests in a dynamically changing world.

Key words: seminatural silviculture, selection forests, transformation strategies, indicators of seminatural silviculture
Un bref survol historique illustre le principal courant de développement de la sylviculture allemande et souligne le rôle adjacent de la sylviculture à tendance naturelle. Le raisonnement soutenant cette sylviculture semi-naturelle est abordé en faisant référence à ses aspects écologiques et économiques. Les éléments de la sylviculture semi-naturelle du concept de Baden-Württemberg sont introduits. Ce concept ne constitue pas uniquement une stratégie de conservation, mais reconnaît l'importance de la production ligneuse. Certains aspects des forêts aménagées par coupes sélectives, tel le cas spécial des forêts inéquiennes établies depuis longtemps dans le sud-ouest de l'Allemagne, sont mentionnés. Comme il existe encore plusieurs forêts équiennes (pures) dans le sud -ouest de l'Allemagne, des stratégies de transformation vers des forêts mélangées inéquiennes sont illustrées à l'aide de quelques exemples.

Les critères et les indicateurs de la sylviculture semi-naturelle qui ont été élaborés au niveau régional ou local, peuvent être utilisés en tant que base d'élaboration du processus de certification des forêts du sud-ouest de l'Allemagne. La sylviculture semi-naturelle constitue adéquatement un système sylvicole rationnel et intégrant, permettant de satisfaire les exigences futures rattachées aux forêts dans un monde en perpétuel changement.

Mots clés: sylviculture semi-naturelle, forêts aménagées par coupes sélectives, stratégies de transformation, indicateurs de sylviculture semi-naturelle

\section{Introduction}

For the past two centuries, the mainstream Central European silvicultural system has favoured pure, even-aged stands. Naturally-oriented silviculture has been mostly disregarded, especially from state forest administrations. Nevertheless a special kind of seminatural silviculture developed in Germany: the so called "naturgemäße Waldwirtschaft", which was only practiced in a few forest districts and survived in West Germany as well as in East Germany.

Problems like global climate change, decreasing biodiversity and recreational demands in general have triggered a new discussion about adequate silvicultural systems in the last two decades. In several European countries, programs were developed which comprise elements of a more naturallyoriented silviculture (these programs are referred to as ecological forestry, seminatural silviculture or naturally-oriented silviculture). These systems attempt to reach both production and environmental targets, yielding a high production of wood with high quality while maintaining natural (biological) processes.

In this paper, elements of seminatural forestry, along with an historical summary, are presented and discussed within a Southwest German scope.

\footnotetext{
${ }^{1}$ This article is the written version of a lecture held at the faculty of forestry of the University of Toronto on 25 January 1996.

${ }^{2}$ Institute of Forest Growth, University of Freiburg, Freiburg, Germany.
}

\section{Historical Overview of Seminatural Silviculture in Germany}

The following historical aspects and development lines in silviculture are not only typical for Southwest Germany, they are, with some local differences, valid for all of Germany.

The brief report of the main developments in forestry in general seems to be important to understand why naturallyoriented silviculture was (with a few exceptions, which are to be reported) not a major movement until the end of the 20th century.

After the vast destruction of German forests in the 18th and early 19th century, a period of forest reconstruction began. With the establishment of the first forest laws, for example the forest law of the former state of Baden in the year 1833, regulated forestry with silvicultural planning was introduced in forestry. Emphasis in forest activity was laid on the establishment of mostly pure stands of conifer tree species (Norway spruce and Scots pine). Two reasons are responsible for the significant change of tree species used in Germany from $60-70 \%$ of broadleaved trees in the 14th century to $60-70 \%$ of coniferous tree species in the early 20th century (Mantel 1990) ${ }^{3}$ :

1. The reestablishment of stands on huge clear cut sites was easier using robust pioneer species of conifers.

\footnotetext{
${ }^{3}$ In private forests of the Black Forest spruce increased from 30\% in the second half of the 19 th century to $80 \%$ at the present time.
} 
2. Changing basic conditions for forestry during the period of industrial revolution and population growth resulting in greater and new demand for wood products (long timber) and new possibilities of distributing wood (development of a railway network during the second half of the 19th century) lead to a preference for fast growing tree species with straight timber.

A number of negative practices for the forests, such as cattle grazing in the woods and irregular exploitation, both declined during the 19th century, so that a long period of conservation and capitalization of forests began. The state forests made major contributions to the state budgets, for example 10-20\% in the former state of Württemberg in the period between 1840 and 1880 (Ott 1987). The relative value of timber was quite high. For example, between 1850 and 1880, by selling $1 \mathrm{~m}^{3}$ of wood, 40-60 hours of labour could be paid for (Brandl 1987) in relation to today. The additional functions of forests were at least partly already appreciated, such as the protection of forests against poor climatic conditions (i.e. cold winds) in higher elevations of the Black Forest. The multiple use of forests was finally accepted as a suitable concept for forestry in Central Europe with the beginning of the post Second World War period.

Altogether three periods of naturally-oriented silviculture (or periods of mixed forests) can be distinguished during the last 100 years in Germany and this is also the case for Southwest Germany (Huss 1987; Otto 1993) (Fig. 1).

Towards the end of the 19th century, Karl Gayer, silviculturist at Munich university, published his famous book "Der gemischte Wald" (The Mixed Forest) (Gayer 1886). He promoted natural regeneration and the establishment of mixed stands. Gayer believed that this non-schematical silvicultural system would lead to more diverse and structured stands. From this period onwards, several systems of natural regeneration were developed and put in practise (mostly in mountainous regions of southern Germany). Gayer's ideas were adopted by Möller

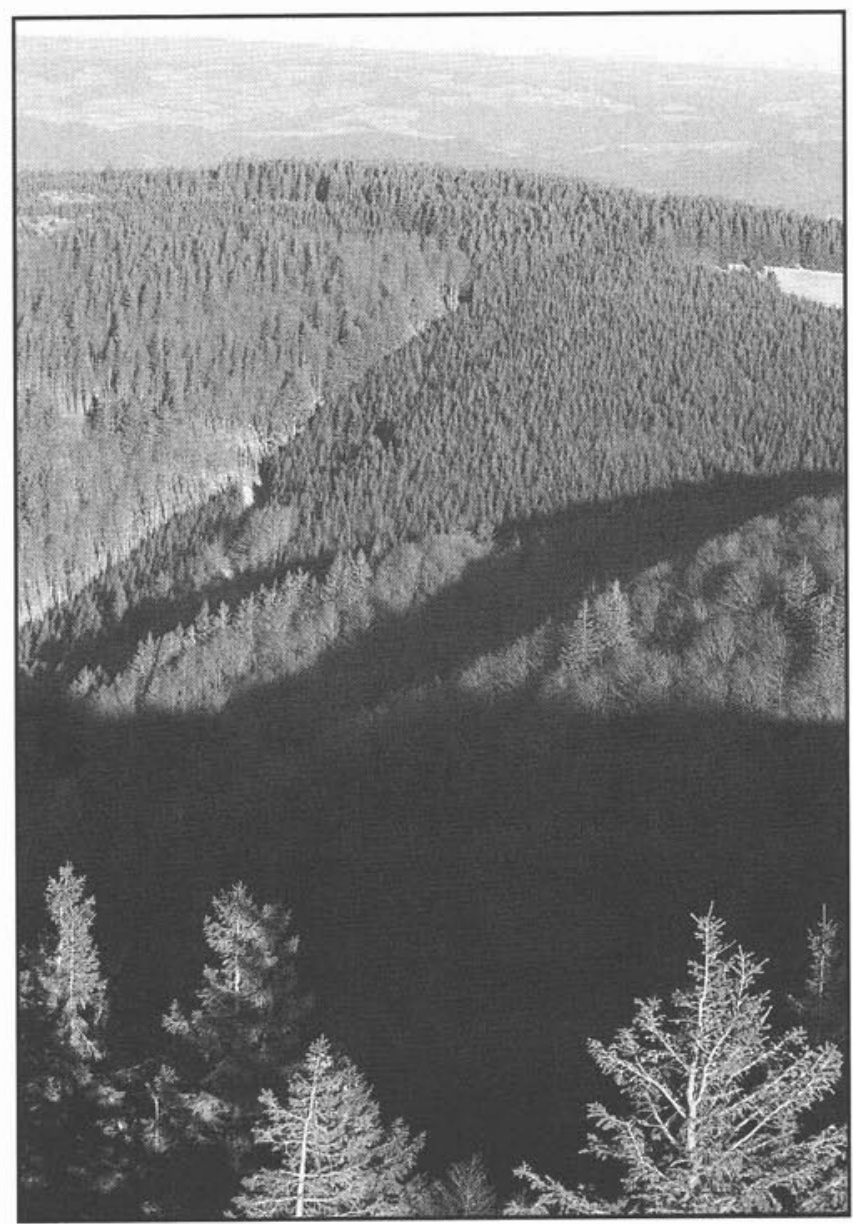

View from the Schauinsland mountain ( $1284 \mathrm{~m}$ above sea level) near Freiburg into the mountanous zone of the Black Forest. In front: evenaged management of beech, spruce and Douglas fir. (Photo Peter Spathelf.)

P. Spathelf, Institute of Forest Growth

University of Freiburg

1850 1900 1950 .2000

time scale

\author{
GAYER 1886 \\ mixed stands \\ natural regeneration systems
}

MÖLLER 1922

concept of ,Dauerwald“"

avoidance of clear cut

\author{
naturally-oriented \\ silviculture \\ multiple use forestry \\ biodiversity and \\ nature conservation
}

Fig. 1. Main phases of naturally-oriented silviculture in Germany from the end of the 19th century. 
in the 1920's and developed into the theory of "Dauerwald" (permanent forest). The view and treatment of forests as organisms was seen as ecologically and economically advantageous. The increase in the value of standing volume without interruption of the canopy and the maintenance of soil quality should (in the eyes of the protagonists of this system) lead to higher sustained revenues. On the other hand the concept of "Dauerwald" coincided with a back-to-nature movement and a critizism of modernism in parts of the German society at that time.

Seminatural forestry is a major development line in the Swiss silvicultural tradition and has influenced German silviculture for decades. The selection and group selection system is widely applied in the Swiss Jura and the Alps (Schütz 1994). Concerning the selection system in hardwood stands, some experiences of French foresters like Perrin become more recognized today. Coppice stands with standards with a low standing volume ("futaie claire") allow the application of the group selection system for more light-demanding species (Schütz 1992).

In Germany, the concept of "Dauerwald" was adapted by a few private forest owners and defended heavily against the advocates of even-aged management during the following decades. During the last two decades, a new trend to more naturally-oriented silviculture became evident all over Europe. The driving forces behind this development are the maintenance of multiple-use-functions, the minimization of production risks in forests, the reduction of costs and last but not least the increasing importance of ecological aspects in most areas of life (change of paradigm).

It is important to note that German foresters had to practise silviculture without the guidance of natural forests. A century ago their challenge was to face high-graded, grazed forests with low standing volume (Weetman 1996). For a long time the selection system was regarded in a pejorative manner because emphasis was laid on selective cutting of big and valuable timber (high-grading) and no care was taken to tending aspects. This may be one reason for the fact that the regulated, evenaged forest with clearcutting or shelterwood regeneration was established as the main silvicultural systems, at least in conifer stands.

\section{Forestry Goals with Seminatural Silviculture}

What is the rationale of seminatural silviculture? What are the advantages of this silvicultural concept?

With seminatural silviculture, both the main targets of German forestry are attempted to be achieved, the production of high quality timber and the maintenance of the multiple-use functions of forests. Germany has around 30\% land area under forestry ( $37.8 \%$ in the state of Baden-Württemberg). Soil and water protection, recreation in forests and some aspects of nature conservation are goals which can be achieved together with the production of valuable timber.

Seminatural silviculture is a silvicultural concept, which lays emphasis on the management of mixed forests with siteadapted species and the avoidance of clear cut harvesting as far as possible. Effects considered to be positive are listed below: 1. By avoiding large clear cut harvesting the natural nutrient cycles will be less disturbed (loss of nutrients after clear cuts of up to $20 \%$ have been reported, Parviainen 1994).

2. In stands with higher structural diversity, a balanced microclimate supports more constant growth conditions.

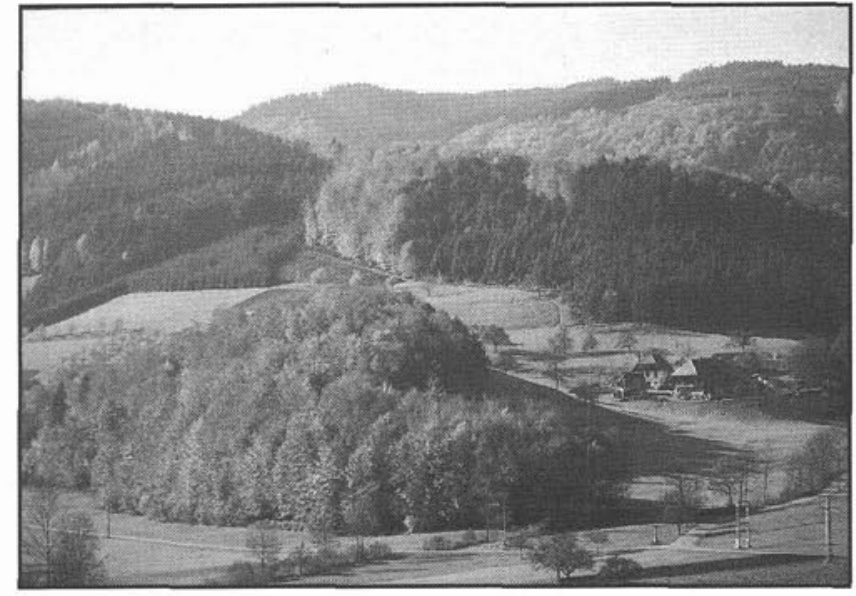

Beech and Norway spruce forests (private forest land) around a solitary farmhouse in the central Black Forest. (Photo Peter Spathelf.)

Possible stresses resulting from an interruption of the canopy (e.g. heavy release of trees) are diminished.

One of the hypotheses for the decline in the silver fir (Abies alba Mill.) in Germany is that changing microclimatic conditions can cause needle loss because of disturbances in water supply due to higher transpiration and insufficient adaptation of root systems. Mainly silver firs with small crown ratios are endangered (Spiecker 1986; Damsohn 1995). 3. Seminatural silviculture may result in higher species and structural biodiversity ${ }^{4}$, because accompanying tree species are tolerated in every development stage of the stands.

In the last few decades, tree rotation age in BadenWürttemberg increased (Weidenbach et al. 1989); the consequences are more trees in mature phases in the stands with possible increase of biodiversity of animals, namely certain bird species (Nipkow 1995).

Biodiversity within the concept of seminatural silviculture can also be increased by smaller management units. Edge effects contribute to a higher landscape diversity of ecosystems (concept of fragmented forest).

An increase of biodiversity is also supported by the introduction and tending of foreign tree species such as Douglas fir, red oak or white pine.

Natural regeneration of locally adapted stands is very important for maintaining genetic diversity.

Nevertheless, if clear cut phases are completely lacking, vegetation formations in special successions as pioneer plant systems cannot exist. Selection forest systems tend to diminish non-shade-tolerant tree species and so reduce species diversity and process diversity.

4. Seminatural silviculture is a strategy for risk minimization: a) Increase in biodiversity (at first tree species diversity) leads to a higher stability against forest protection problems (underplanting of beech in pure pine stands of the Rhine Valley in the first half of the 20th century diminished significantly attacks of pine pests).

\footnotetext{
${ }^{4}$ Biological diversity means the variability among living organisms from all sources including, inter alia, terrestrial, marine and other aquatic ecosystems and the ecological complexes of which they are part; this includes diversity within species, between species and of ecosystems" (Article 2 of the United Nations Convention on Biological Diversity, Rio de Janeiro 1992).
} 


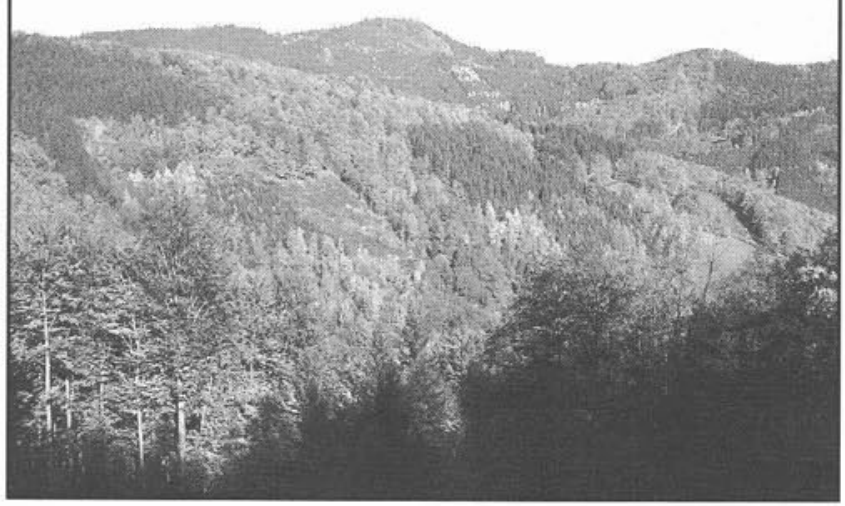

Mixed forest (beech, Norway spruce Douglas fir, Scots pine and silver fir) of different age classes in the Black Forest (Kinzig Valley). (Photo Peter Spathelf.)

b) Management of mixed stands offers the possibility of product diversification in the future.

\section{Elements of Seminatural Silviculture in Baden-Württemberg}

In order to work, seminatural silviculture requires some basic preconditions. Firstly a suitable site classification system must be available. Baden-Württemberg has a long tradition in site mapping; the method consists of a two-step system. On a landscape level geographical units like the Swabian Alb, the Rhine Valley or the Black Forest are separated. These units are called growth districts. On a more regional level the growth districts are divided into smaller areas according to regional climate and topographical differences (Fig. 2).

On a local level, ecoseries (which have a similar soil substrate) and the site units, as the basic ecological units, are mapped (i.e. physiographic site mapping). The basic site units are characterized by a combination of soil and vegetation parameters.

State and communal forests in Baden-Württemberg are mapped completely and nearly all private forests are also mapped. With this, a pragmatic tool is available which is used to support silvicultural decisions.

Secondly, seminatural silviculture in Europe requires a controlled wild game population. Natural regeneration of main tree species should be possible without protective measures. In Baden-Württemberg, every second hunting district shows such low game densities (Von Teuffel 1995, personal communication). In several areas natural regeneration of beech and even silver fir or oak without protection measures is no longer a severe problem.

In 1993, the state forest administration of Baden-Württemberg established a concept of seminatural forestry which comprises of the following elements (MLR Baden-Württemberg 1993):

1. The establishment of mixed stands suited to sites with high structural diversity (selection of species of natural vegetation; foreign tree species are tolerated to a small extent).

2. The natural regeneration of stands wherever possible and rational (exception of natural regenerated accompanying species).
The amount of natural regeneration of state forests in Baden-Württemberg is about $40 \%$ in relation to the whole regenerated area.

3. The application of adequate thinning strategies:

tending of young stands, early and heavy thinning in favour of future crop trees (selection thinning).

4. A great content of dead wood.

5. The avoidance of large clear cut harvesting as far as possible.

6. The observation of succession stages on limited areas.

7. No application of herbicides.

8. The protection of forest soils and remaining stands.

9. The protection of "natural" processes such as self differentiation of stands.

There is common agreement that managing forests with seminatural silviculture conservation goals can, in general, be achieved. Additionally, the special conservation of small forest areas with higher ecological values is supported with a habitat protection program. A network of completely preserved areas in BadenWürttemberg helps to investigate the dynamics of natural processes in different forest types.

Seminatural silviculture in Southwest Germany recognises the importance of wood production. Nevertheless, strategies for the reduction of management intensity on considerable areas is being pursued by a small number of forest owners in Germany (e.g. the city forests of Lübeck) (Fähser 1995).

\section{Selection Forest}

A special case of uneven-aged mixed forest in Central Europe is the selection forest ("Plenterwald"). Real selection forests ${ }^{5}$ are very rare in Central Europe (Table 1) (Schütz 1994), but they are heavily discussed as an ideal type of uneven-aged forest. Moreover they are interesting scientific objects in comparison with even-aged forests, because of their different growth patterns.

Selection forests are characterized by two important facts (after Schütz 1992):

1. Natural regeneration occurs spontaneously and in a sustained manner (self renewing).

2. Trees in selection forests often show typical growth patterns with a generally slow growth (diameter and height growth) in their youth, and a consistent growth rate after release from shelter (Mitscherlich 1952; Spiecker 1986).

Selection forests are interesting silvicultural systems because of some obvious advantages:

Selection forests in general work with natural regeneration, so costs of establishing stands are clearly reduced. Although thinnings in selection forests are also practised in every development stage, in general tending costs are not as high as in even-aged high forests. Due to an early individualization relating to their neighbouring situation, trees in selection forests often develop long crowns. Thus, their individual stability against snow and storm damage (breakages) is high. But it should also be mentioned that high forests which are thinned using modern concepts (early and heavy thinnings in favour of future crop trees) do differ significantly from selection forests relating to

$\overline{{ }^{5} \text { Real selection forests are characterized by the typical negative exponential }}$ stem number distribution curve. 


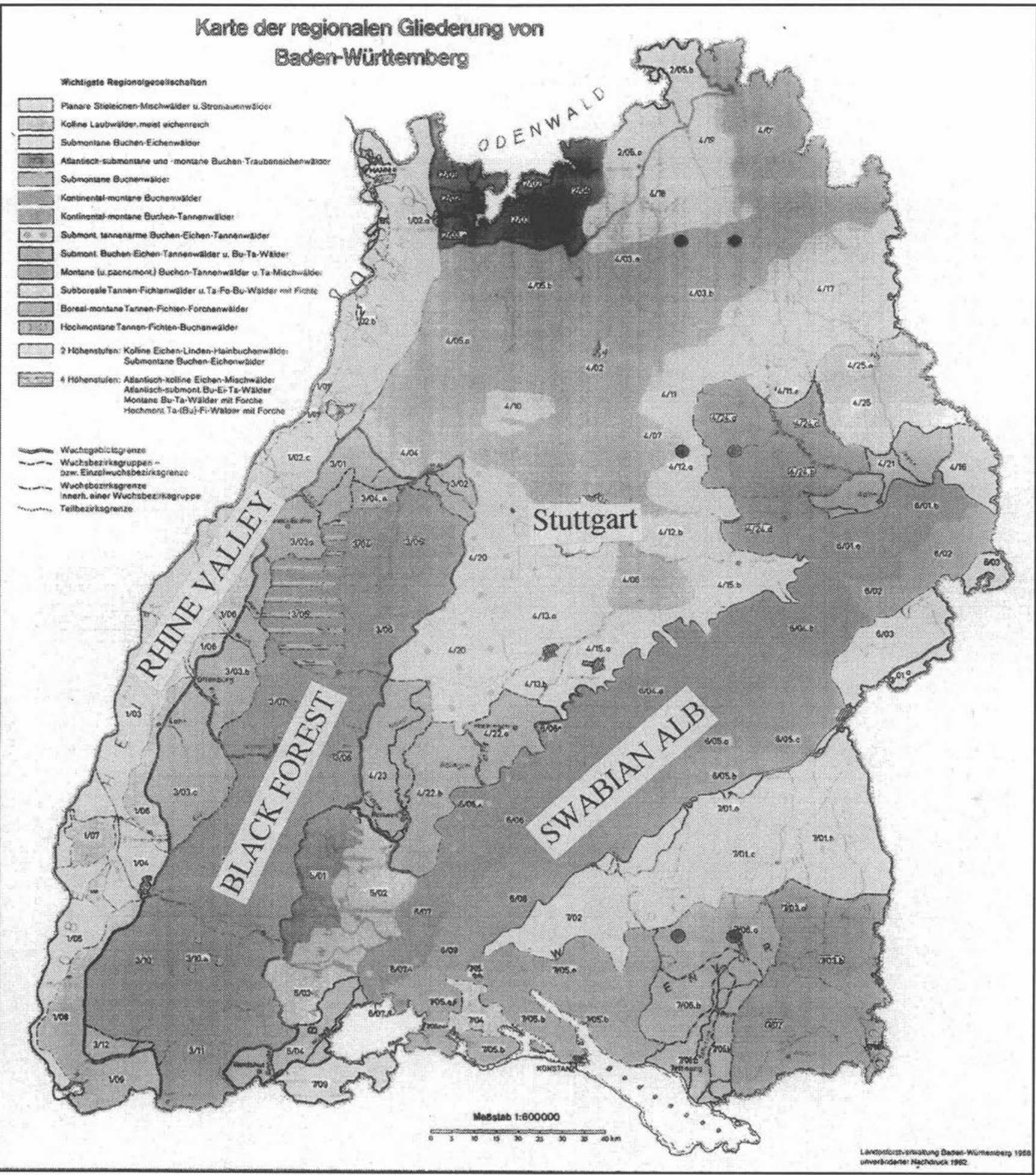

Fig. 2. Map of growth districts in Baden-Württemberg.

stability. They are more stable against storm damage due to a less rough canopy surface. Another advantage of selection forests is that there are less disturbances in the nutrient cycle because of the lack of large clear cut surfaces.

Disadvantages of selection forests are the need of permanent cuttings in all parts of the stands to maintain their artificial structure and their relatively monotonous structure on stand level. Therefore it is likely that selection forests show lower biological diversity in the long run in comparison to evenaged high forests. Lack of cuttings increases the mortality of small trees because of shade and reduces vitality of larger trees which develop smaller crowns. On the other hand, sudden heavy cutting reduces the vitality of the remaining trees (Spiecker 1986). A selection forest is an artificial forest structure which needs continuous massive interventions by skilled managers and forest workers. Managers have to make their cutting 
Table 1. Share of selection forests in mountanous regions of Southern Germany, the Alps and Slovenia (after Schütz 1994).

\begin{tabular}{|c|c|c|}
\hline Region & $\begin{array}{l}\text { Percentage of selection forest } \\
\text { within the total forested areas }\end{array}$ & Source \\
\hline Switzerland & 8,4 & Schweiz. Landesforstinventar 1992 \\
\hline Baden-Württemberg & 3,5 & Bundeswaldinventur 1987 \\
\hline Allgäu/Bregenzerwald & 12 & Estimation \\
\hline Slovenia & 18 & Estimation \\
\hline
\end{tabular}

decisions on the basis of the individual conditions of the tree and its neighbours. Tending, thinning and pruning are essential for high quality timber production.

In addition, selection forests need a good access with permanent roads. Thus the selection system is not a priori a feasible silvicultural system for unlogged and dense oldgrowth stands in western North America (Weetman 1996).

An interesting historical note is that selection forests in the former state of Baden were forbidden by forest law in 1833 . State foresters didn't practise the selection system over a number of decades, but farmers in the Black Forest opposed to the law until the beginning of the 20th century and thus preserved most of the few selection forests which survive today.

\section{Silvicultural Strategies Towards Seminatural Silviculture}

A huge amount of work is required if seminatural silviculture is to be practised on a large scale, as this involves the transformation of pure even-aged stands into uneven-aged mixed stands. Using examples from Baden-Württemberg, some transformation strategies are presented. The examples are grouped into two phases, the regeneration and the thinning phase.

\section{Regeneration Phase of Stands}

a) On the Swabian Alb many pure-even-aged spruce stands grow on non-suitable sites. A main silvicultural goal in these areas is the conversion of these stands into broadleaved stands of beech (with ash and maple sp.). To achieve this, spruce stands are underplanted with beech over the entire area $10-30$ years before the end of the rotation (i.e. harvesting).

b) In stands where the site is suitable for spruce, beech is underplanted on a part of the area (30-40\%): the stocking goal is a mixed stand composed of spruce and beech with the option to regenerate beech naturally for the next stand generation.

c) Transformation of more or less even-aged spruce and spruce/fir stands into uneven-aged mixed stands or selection forests respectively is a common silvicultural goal in the area in which silver fir is naturally distributed: the higher elevations of the Black Forest. The applied technique here is underplanting (of beech and silver fir) in groups or the utilization of natural regeneration.

d) If stands are established after clear cut (e.g. oak after spruce on non-suitable sites) wider spacing of plants is favourable in order to support the growth of accompanying species such as birch or willow. Incorporating species of the natural succession is an important tool to enrich pure stands and so to increase biodiversity.

\section{Tending and Thinning of Stands}

To maintain broadleaved trees in conifer stands, adequate treatment of these species is necessary; future crop tree selection and consequent thinning are measures used to achieve this goal.

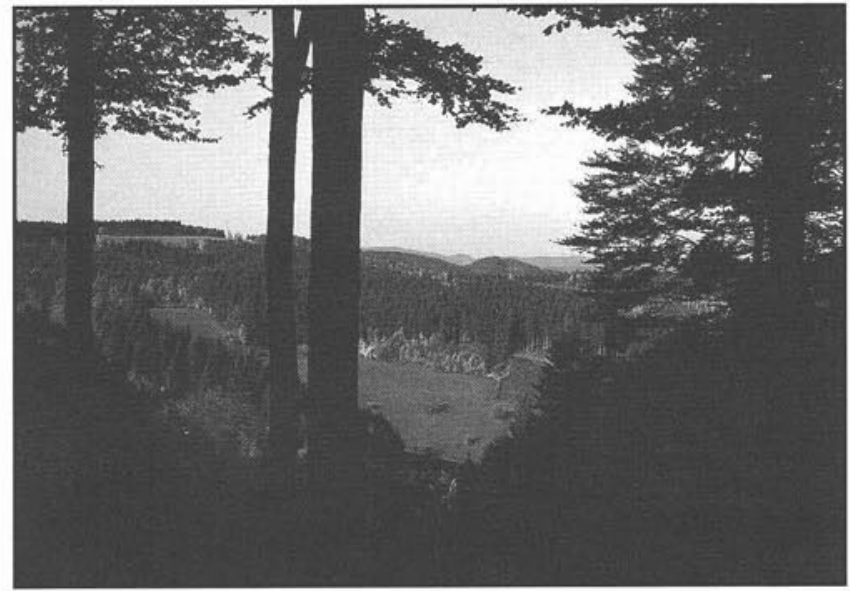

Private forests (silver fir, Norway spruce and beech) in the central Black Forest; typical landscape impression. (Photo Peter Spathelf.)

Transformation of pure even-aged stands into unevenaged mixed stands requires stable sites and the possibility of maintaining old trees in the upper storey. If one cannot work with the old trees, it is necessary to develop an uneven-aged next stand generation by means of long-term natural regeneration (Schütz 1989).

Skovsgaard (1995) illustrated the possible paths towards naturally-oriented silviculture, remarking that naturallyoriented silviculture is a option with a "partially unexplored or unknown target situation" because of a mostly insufficient quantitative (i.e. experimental) basis (Fig. 3).

Quantitative tools for growth control in these transformation phases are lacking. At the Institute of Forest Growth (University of Freiburg), we are working on this subject in a project entitled "Growth Response of Silver Fir and Norway Spruce After Heavy Release". In this project a (decision) tool for controlling growth patterns with the aid of crown ratio will be developed.

Lack of information also exists in other scientific fields concerning transformation strategies:

1. Impact on volume increment and value production of stands.

2. Proof of negative genetic effects due to goal-diameter cuttings or selection "plenter" thinning.

\section{Possible Criteria of Seminatural Silviculture}

The discussion concerning certification of wood production in naturally-oriented forests in Germany requires the establishment of criteria and indicators in order to characterize the kind of silvicultural system to be used. Some possible criteria of seminatural silviculture are listed in the following table (Table 2):

A great deal more work is required to create indicators which would make it possible to measure to which extent forests are 


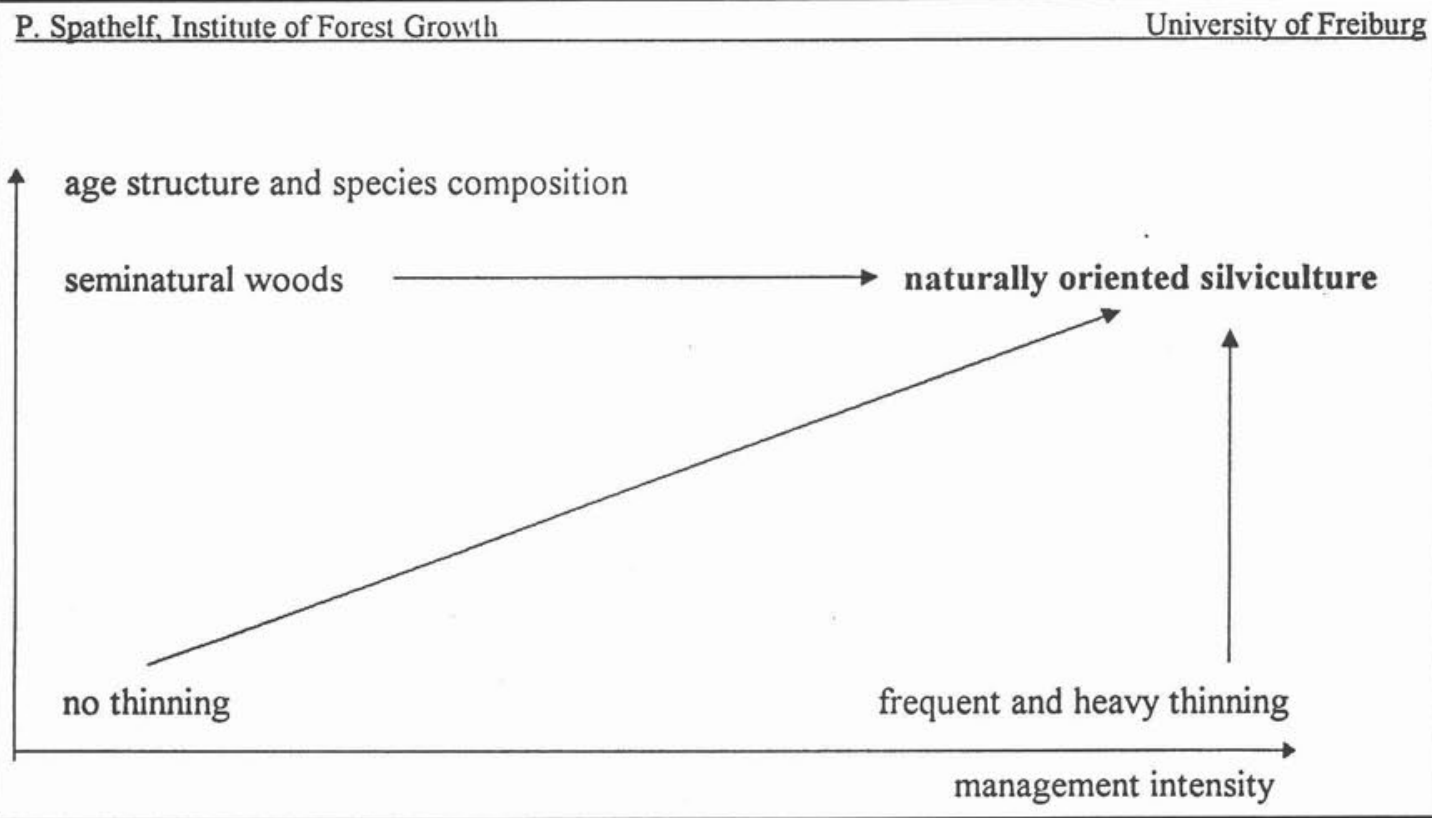

Fig. 3. Silvicultural options illustrating the possible paths towards naturally-oriented silviculture (after Skovsgaard 1995).

managed in a seminatural manner. It seems to be very important that regional or local target levels relating to the developed indicators of seminatural silviculture are defined.

\section{Discussion and Conclusion}

Seminatural silviculture in Southwest Germany is now basically a widely accepted concept of silviculture practise within the forestry community. It is a model with an integrating impact among the different professions working in forestry.

Nevertheless, there remains some controversy in Germany between the nature protection lobby and representatives of state forest administrations. This is particularly the case after the publication of a report on seminatural forestry in Central Europe sponsored by Greenpeace (Sturm 1994). A central component of this concept is the preservation of natural processes (i.e. process protection). According to this report, wood production should only play an adjacent role; nearly all silvicultural measures, which work against natural processes in forests are rejected. Naturally-oriented silviculture of this kind has to preserve the variety of those natural processes, because it cannot control them. Reference areas (at least $10 \%$ of the forest area of a German state) are proposed, where complete conservation is achieved.

It has been consistently commented by representatives of state forest administrations that "process protection" is not a goal of forestry in itself. Therefore process protection cannot be the basis for a silvicultural system where a main goal remains timber production. The discussion concerning the adaptability of our silvicultural measures, regarding the changing requirements of the society on forests and forestry, is ongoing. There is general agreement that a great deal of research on natural processes in the forests and the impact of silvicultural measures on the forest ecosystems is lacking. Furthermore, a major task will be the clearer foundation and permanent adaptation of our silvicultural objectives. These are preconditions for a more rationally based silvicultural system. In future silvicultural measures have to be considered on an ecosystem

\begin{tabular}{ll}
\hline Table 2. Possible criteria of seminatural silviculture \\
\hline Natural criteria & Economical criteria \\
\hline Number of species of stands & Management intensity \\
Species composition of stands & Cost structure ${ }^{1}$ \\
Age structure of stands & \\
Vertical structure of stands & \\
Share of natural regeneration & \\
Size of management unit & \\
\hline
\end{tabular}

${ }^{1}$ Possible cost quantities of naturally managed forest stands in comparison to even-aged pure forest stands in Germany was analyzed e.g. by KÖPSELL (1983).

and landscape level. That means that silviculture develops from stand management to a extensive ecosystem management. Last but not least, seminatural silviculture is most likely capable to meet the challenges of further changing environmental conditions such as increasing nitrogen deposition rates (Spiecker et al. 1996).

\section{Acknowledgements}

The author thanks the Faculty of Forestry of the University of Toronto (Canada) for the opportunity to give lectures during the week of January 22.-27., 1996 and Dr. Weetman, Faculty of Forestry, University of B.C. for helpful comments.

\section{References}

Brandl, H. 1987. Zur Geschichte der Wirtschaftlichkeit in der Forstwirtschaft. AFZ 42: 1019-1023.

Damsohn, W. 1995. Zur Symptomatologie der gesunden und walderkrankten Tanne. Diss. Hohenheim. 348 S. und Anhang S. 351-491.

Fähser, L. 1995. Das Konzept der Naturnahen Waldnutzung im Stadtforstamt Lübeck. Der Dauerwald 12: 2-6.

Gayer, K. 1886. Der gemischte Wald. Paul Parey, Berlin.

Huss, J. 1987. Mischwald zwischen Wunsch und Wirklichkeit. FowCbl 106: 114-132.

Köpsell, R. 1983. Charakteristische Kennziffernstrukturen naturgemä§ bewirtschafteter Forstbetriebe. Forstarchiv 54: 83-89. 
Mantel, K. 1990. Wald und Forst in der Geschichte. M.\&H. Schaper, Alfeld-Hannover.

Mitscherlich, G. 1952. Der Tannen-Fichten-(Buchen)-Plenterwald. Schr.r. d. Bad. FVA 8.

Ministerium für Ländlichen Raum, Ernährung, Landwirtschaft und Forsten Baden-Württemberg. 1992. Broschüre Naturnahe Waldwirtschaft. Stuttgart. $32 \mathrm{~S}$.

Nipkow, T. 1995. Ein synoptischer Verfahrensansatz zur naturschutzfachlichen Gebietsbewertung auf der Basis multivariater Analysemethoden. Schriftenreihe des Instituts für Landespflege der Universität Freiburg. Heft 20. $156 \mathrm{~S}$.

Ott, W. 1987. Die Ertragslage der Forstwirtschaft. Entwicklungen - Perspektiven - Konsequenzen. AFZ 42: 399-403.

Otto, H.-J. 1993. Waldbau in Europa - seine Schwächen und Vorzüge - in historischer Perspektive. FoHo 48: 235-237.

Parviainen, J. 1994. Ist Waldnutzung ohne Kahlschlag möglich? AFZ 49: 895 .

Schütz, J.-Ph. 1989. Le régime du jardinage. Document autographique du cours de silviculture III. Chaire de silviculture, ETHZürich. $55 \mathrm{p}$.

Schütz, J.-Ph. 1992. Die waldbaulichen Formen und die Grenzen der Plenterung mit Laubbaumarten. SZFW 143: 442-460.

Schütz, J.-Ph. 1994. Geschichtlicher Hergang und aktuelle Bedeutung der Plenterung in Europa. AFJZ 165: 106-114.
Skovsgaard, J.P. 1995. Challenges for the modelling of growth and yield in mixed stands with a naturally-oriented silviculture, based on experiments in pure even-aged stands and on evidence from non-intervention forest sites: The present situation in Denmark. DVFFA, Sekt. Ertragskunde, Ber d Jahrestagung. Joachimstal.

Spiecker, H. 1986. Das Wachstum der Tannen und Fichten auf Plenterwald- Versuchsflächen des Schwarzwaldes in der Zeit von 1950-1984. AFJZ 157: 152-164.

Spiecker, H., K. Mielikäinen, M. Köhl and J. Skovsgaard. (eds.) 1996. Growth Trends in European Forests - Studies from 12 Countries. European Forest Institute Research Report 5. Berlin: Springer-Verlag: $372 \mathrm{~S}$.

Sturm, K. 1994. Naturnahe Waldnutzung in Mitteleuropa. Gutachten im Auftrag von Greenpeace Deutschland. $48 \mathrm{~S}$.

United Nations Convention on Biological Diversity. 1992. Article 2. Rio de Janeiro.

Weetman, G.F. 1996. Are European Silvicultural Systems and Precedents Useful for British Columbia Silviculture Prescriptions? Canada-British Columbia Partnership Agreement on Forest Resource Development: FRDA Report 239. Victoria, BC. 31 p.

Weidenbach, $P$. et al. 1989. Waldbauliche Ziele und Forsteinrichtungsergebnisse im öffentlichen Wald in BadenWürttemberg. Schriftenreihe der Landesforstverwaltung BadenWürttemberg. Band 69. 